\title{
DETERMINANT OF EMPLOYEE PERFORMANCE IN SALES DEPARTMENT OF PT. DUNIA BARUSA ACEH WITH PERSONALITY COMPOSITION AS MODERATION VARIABLES
}

\author{
Muhammad Taufik, Nasir and Teuku Roli Ilhamsyah Putra \\ Magister Manajemen, UniversitasSyiah Kuala, Indonesia \\ http://doi.org/10.35409/IJBMER.2020.3188
}

\begin{abstract}
This study was conducted aiming to determine and test the effect of transformational leadership and interaction competency on employee performance in the sales department, personality composition as a moderating variable at PT DuniaBarusa Aceh. The population used was all employees of the car sales department at PT. DuniaBarusa in Banda Aceh, Lhokseumawe and Meulaboh numbered 180 people. The research model was analyzed using Structural Equation Modeling (SEM) through the Amos application. Data was collected through questionnaires that used the Likert scale. The result found that transformational leadership and interaction competency have a significant effect on employee performance. Furthermore, personality composition can strengthen the influence of transformational leadership on employee performance. Personality composition can strengthen the effect of interaction competency on employee performance. This study provides managerial implications that to improve the performance of its employees, especially in the sales departmentat PT. DuniaBarusa Aceh, what needs to be done is to increase transformational leadership, interaction competency and employee personality composition. The findings in this study can contribute to the renewal of theory and practically also produce solutions for research objects. Personality composition becomes the development and adaptation of interesting theories to the object of research, which can strengthen other variables. The limitation of the study is the number of variables studied and the scope of the study
\end{abstract}

Keyword: Transformational Leadership, Interaction Competency, Employee Performance, Personality Composition.

\section{INTRODUCTION}

Today's business competition is getting tougher. The automotive business sector is a business with a scale that is not easy to enter, but in Indonesia this business sector is quite popular due to its large population, has a varied income scale, and the vast archipelago so that the transportation business, especially those selling car products, has a market opportunity which is quite promising. To get the attention and satisfaction of consumers, an automotive company especially in Indonesia of course must have advantages when compared with other competitors. In the automotive world, car dealerships are also very dependent on the competence of their human 


\section{International Journal of Business Management and Economic Review}

Vol. 3, No. 04; 2020

ISSN: 2581-4664

resources, namely employees in the process of selling their products. High car sales in Indonesia is a result of the high demand of the community for transportation facilities, this can be seen from the total car sales in the 5 biggest car brands in Indonesia as shown in the following table.

Table 1. Car Sales in Indonesia as of November 2019

\begin{tabular}{|l|l|l|l|}
\hline N0 & Brand & Marketing 2019 & $\%$ \\
\hline 1 & Toyota & 304.344 & 38.26 \\
\hline 2 & Daihatsu & 166.429 & 20.29 \\
\hline 3 & Honda & 125.034 & 15.72 \\
\hline 4 & Mitsubishi Motors & 109.195 & 13.73 \\
\hline 5 & Suzuki & 90.267 & 11.35 \\
\hline \multicolumn{2}{|l|}{ Total } & 795.269 & 100 \\
\hline
\end{tabular}

Source:Gaikindo(2020)

From the table above it can be seen that the Toyota company has very high sales in Indonesia at $38.27 \%$, while Daihatsu and Honda are at $20.93 \%$ and $15.72 \%$ for Mitsubishi and Suzuki sales levels of $13.73 \%$ and $11.35 \%$ so that the total sales of 5 companies namely 795,269 units of cars in 2019 (sales as of November).

The success of a company is strongly influenced by the performance of its employees. Therefore, every company will certainly always try to think about how to improve the performance of its employees to achieve the highest achievements according to planned goals. A company culture that grows and is also properly maintained will certainly be able to spur the company towards better growth and development. On the other hand, the ability of a leader in terms of moving and also empowering employees will have a major effect on performance achievements.

Even though in terms of total sales increasing, the phenomenon related to sales performance at PT DuniaBarusa Aceh was felt to be still not going well. This can be seen from the many employees who have not been able to meet the sales (marketing) targets set by the company. The same thing is also shown by the inefficient use of time by employees in completing their work, especially in the automotive field. And the low work commitment shown by the employees.

One component in managerial that affects the performance of employees in the company is leadership. The leadership of a company will determine whether or not the company will work, and of course it will produce a certain level of achievement based on company goals. Various attempts are made by a leader to move the employees to be able to do their jobs in accordance with the concept that they should, including by giving a compliment, appreciation, motivation, and vice versa also by giving a pressure on their employees to improve the competitive climate and work spirit within the company. The company needs a leader who can be the driving force for organizational change and a leader who can set specific goals, monitor business growth and development, and identify the types of rewards that employees deserve if the goals can be achieved.

One concept of leadership that often develops in recent years is transformational 


\section{International Journal of Business Management and Economic Review}

Vol. 3, No. 04; 2020

ISSN: 2581-4664

leadership. Transformational leadership refers to the approach used by leaders to motivate employees to meet the company's goals and objectives and employee performance exceeds expectations. Transformational leadership plays an important role in causing the changes needed for effective management.

Other factor that affects employee performance at PT. DuniaBarusaAceh is an Interaction competency. Every human being tends to develop a concept of himself through his interactions with others in society and is done through communication. So, communication is a very effective means of getting to know who we are through other people.

Transformational leadership style and interaction competence are inseparable from the composition of the worker's personality where good characteristics can improve employee performance so that company goals can be achieved. Research conducted by(Wang, 2020)stated that interaction or communication competencies have an impact on better employee performance. This means that As is the case with car dealers PT. DuniaBarusaAceh, various approaches have been taken by its leaders to improve the performance of their salespeople but this will not affect or reduce the welfare of companies and employees, if the composition of personality is low.

So that personality factors really need to be fostered to salespeople by providing advice and providing training according to company standards by company leaders. If none of these things can be done, the company will provide a warning letter to sales or dismissal of employees. Therefore, the character of a person becomes the basis in influencing the process of working and the results obtained.

Judging from the background and phenomena of previous research, researchers have thought to test concepts in the managerial field through a study entitled "The Effect of Transformational Leadership and Interaction Competency on Employee Performance with Personality Composition as Moderation variable in Sales Department of PT DuniaBarusa Aceh.

\section{LITERATURE STUDY}

\section{Employee performance}

Employee performance is the result of an employee's work over a certain period of time compared to various possibilities, for example a standard, target / target or criteria that have been predetermined and agreed upon(Robbins \& Judge, 2014). As according to(Timpe, 2012)performance is the level of achievement of a person or employee in an organization or company that can increase organizational productivity. Meanwhile according to(Frank Ostroff, 1999)performance is as an individual success that can be achieved in doing his work, where the size of an individual's success can not be equated with other individuals. Employee performance can also be interpreted as the achievement of an employee in an organization as measured by the standards and criteria set by the organization(Qadariah, Majid, \& Idris, 2019).

The statement explains that employee performance is a result of work produced by each member or employee within a certain time span. Employee performance refers more to individual achievements as measured by a standard or criteria determined by the company or organization. Based on these explanations, it can also be stated that performance or work performance is a result of work both in quality and quantity that can be produced by an employee within a certain timeframe in accordance with the responsibilities that have been given.

Performance indicators according to (Bernardin \& Russell, 2012)consists of: 1) Quality; 2) 


\section{International Journal of Business Management and Economic Review}

Vol. 3, No. 04; 2020

ISSN: 2581-4664

Quantity; 3) timeliness; 4) Effectiveness; 5) independence; and 6) Employee Commitment.

\section{Transformational leadership}

(Robbins \& Judge, 2014)said transformational leadership can be interpreted as a condition of leaders who provide intellectual consideration and stimulation to individuals and their organizations and have charisma.(Kreitner \& Kinicki, 2013)revealed that transformational leaders can lead to a belief, able to find and develop leadership in others, are willing to sacrifice and have the morale to serve, focus themselves and subordinates on goals that go beyond the more pressing needs of the work group. Transformational leadership transforms employees to achieve organizational goals more than personal interests. According to(Colquitt, LePine, \& Wesson, 2011)Transformational leadership can inspire followers to commit to a shared vision that gives meaning to their work while also simultaneously serving as a role model that helps followers develop their potential and see their own problems from a new perspective.

The indicators of transformational leadership according to(Robbins \& Judge, 2014), covers (1) Charisma, (2) Inspiration (3) Intellectual stimulation, (4) Indivdualized consideration.

\section{Interaction Competency}

Interaction Competencyis the ability in the relationship between one individual with another individual, one individual can influence other individuals or vice versa, so there is a mutual relationship. The relationship can occur between individuals with individuals, individuals with groups or groups with groups(Basri \& Syafrizal, 2017). According to(Mead \& Morris, 1967)every human being develops his own concept through interaction with others in society and is done through communication. The role of informal communication in youth organizations must not be ignored(Whittaker, Frohlich, \& Daly-Jones, 1994). Good communication in an organization will help learning and changing information(Kreitner \& Kinicki, 2013).

Interaction Competency Indicators according to (Wibowo, 2015)is (1) Can manage social relationships with others. (2) Get feedback quickly. (3) Interact with other people by using several tools. (4) Communicating with several people at once. (5) Can interact with other people wherever they are. (6) Easy conversations with other people.

\section{Personality Composition}

Personality according to(Allport, 1943)can be interpreted as a dynamic organization in individuals which is a psychophysical system that determines the characteristics of behavior and thoughts of a person or individual. Personality has also been described by (Hall \& Lindzey, 1993)which stated that personality is as the most prominent appearance or impression, which is shown by someone to another person. Other opinions have also been expressed by(Derlega, Winstead, \& Jones, 2004)which defined personality as a relatively stable system of individual characteristics that are internal, which contribute to thoughts, feelings, and consistent behavior.

Indicator composition of personality according to (Greenhaus \& Callanan, 2006)include: (1) Openness to experience, (2) Conscientiousness, (3) Extraversion, (4) Agreeableness (5) Neuroticism.

\section{Research paradigm}

Based on the discussion of the problem and research literature, the researcher formulates the 
Vol. 3, No. 04; 2020

ISSN: 2581-4664

research paradigm and hypothesis as follows.

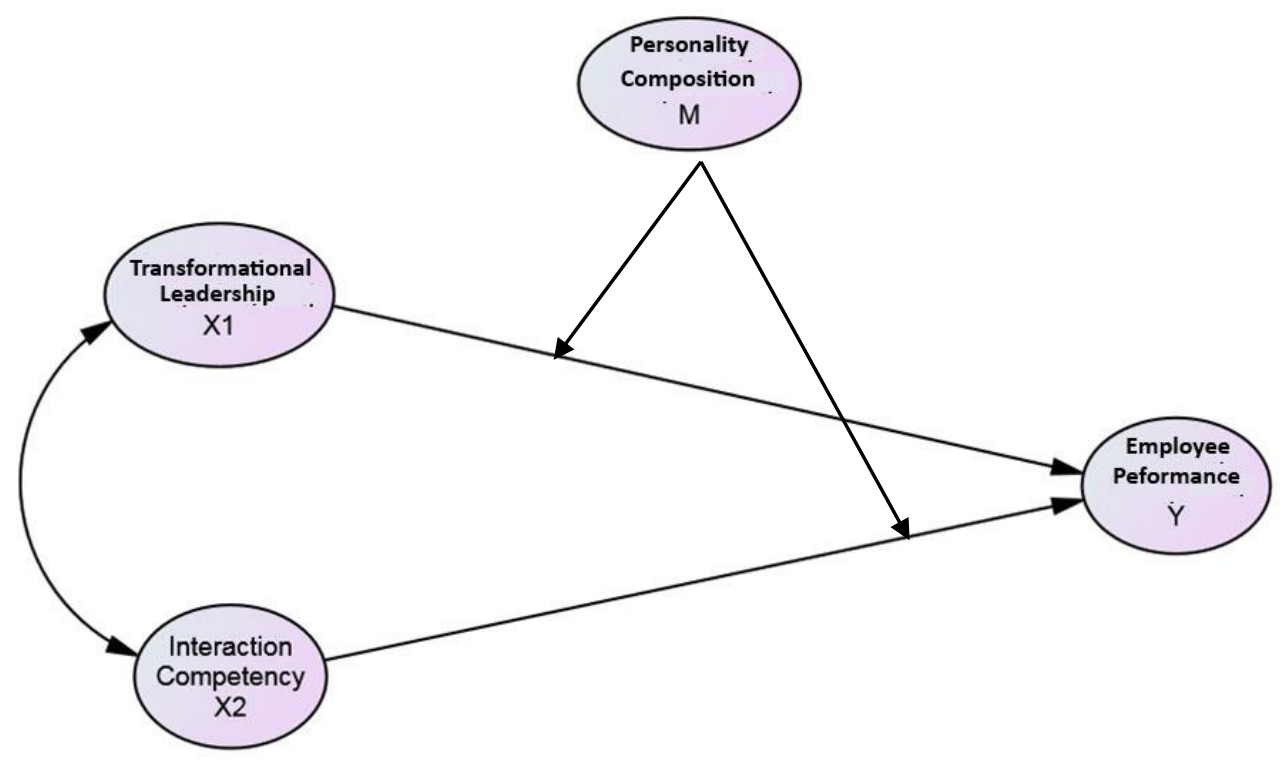

Figure 1. Research Model

Ha1: Transformational leadership, Interaction competency, personality composition and employee performance have been going well.

Ha2: Transformational leadership has an influence on employee performance

Ha3: Interaction competency has an influence on employee performance

Ha4: Personality Composition has a moderating effect on transformational leadership on employee performance

Ha5: Personality Composition has a moderating effect on Interaction competency on employee performance.

\section{RESEARCH METHODS}

This research was tested at PT. DuniaBarusa, While the object of research is employees who work at the Dealer. The population used was all car sales employeeat PT. DuniaBarusa in Banda Aceh, Lhokseumawe and Meulaboh numbered 180 people. The research model was analyzed using Structural Equation Modeling (SEM) through the Amos application. Data was collected using a questionnaire that used the Likert scale. Equipment for data analysis used in this study was the MRA (Moderate Regression Analysis) method or also often called moderated Hierarchical Regression Analysis(Baron \& Kenny, 1986).

The SEM equation model is described as a set of statistical techniques capable of simultaneously testing a series of relatively complex relationships(Hair, Hult, Ringle, \& Sarstedt, 2016).SEM is able to enter latent variables into the analysis. Before testing the hypothesis, confirmatory factor analysis (CFA). CFA in SEM needs to be done to ensure that the indicators 


\section{International Journal of Business Management and Economic Review}

Vol. 3, No. 04; 2020

ISSN: 2581-4664

are fit(Silva \& Alwi, 2008).

The moderating variable in this study is the personality composition. Moderation variables can be clarified into 4 types of moderation, namely pure moderation, pseudo moderation, potential moderation, and moderator as predictor(Ghozali, 2017). Each moderation can be identified as the equation below, that is, if symbol $\mathrm{X}$ is a predictor variable, $\mathrm{Y}$ is a dependent variable, and $\mathrm{M}$ is a variable variable, then a regression equation can be formed in this study:

1) $Y_{1}=b_{0}+b_{1} X_{1}+b_{2} X_{2}$ (without involving moderation variable)

2) $Y_{1}=b_{0}+b_{1} X_{1}+b_{2} M_{i}+b_{3} X_{2}+b_{4} M_{i}($ involving moderation variable $)$

3) $\mathrm{Y}_{1}=\mathrm{b}_{0}+\mathrm{b}_{1} \mathrm{X}_{1}+\mathrm{b}_{2} \mathrm{M}_{\mathrm{i}}+\mathrm{b}_{3} \mathrm{X}_{1} * \mathrm{M}_{\mathrm{i}}+\mathrm{b}_{4} \mathrm{X}_{2}+\mathrm{b}_{5} \mathrm{M}_{\mathrm{i}}+\mathrm{b}_{6} \mathrm{X}_{2} * \mathrm{M}_{\mathrm{i}}$ (involving moderation and interaction variables)

\section{RESULT AND DISCUSSION}

Descriptive Hypothesis Testing

Table1. One Sample T-Test

\begin{tabular}{|l|l|l|l|l|l|l|}
\hline & \multicolumn{9}{|l|}{ Test Value $\mathbf{3 . 4 1}$} \\
\cline { 2 - 7 } & T & Df & $\begin{array}{l}\text { Sig. } \\
\text { (2-tailed) }\end{array}$ & $\begin{array}{l}\text { Mean } \\
\text { Difference }\end{array}$ & $\begin{array}{l}\text { 95\% Confidence Interval } \\
\text { of the Difference }\end{array}$ \\
\cline { 3 - 7 } & & Lower & Upper \\
\hline $\begin{array}{l}\text { Transformational } \\
\text { leadership }\end{array}$ & 47.796 & 179 & 0.000 & 10.72889 & 10.2859 & 11.1718 \\
\hline $\begin{array}{l}\text { Interaction } \\
\text { Competency }\end{array}$ & 50.357 & 179 & 0.000 & 17.69000 & 16.9968 & 18.3832 \\
\hline $\begin{array}{l}\text { Employee } \\
\text { Peformance }\end{array}$ & 65.189 & 179 & 0.000 & 17.97889 & 17.4347 & 18.5231 \\
\hline $\begin{array}{l}\text { Personality } \\
\text { Composition }\end{array}$ & 50.201 & 179 & 0.000 & 13.96778 & 13.4187 & 14.5168 \\
\hline
\end{tabular}

Source: Primary Data, 2020 (processed)

Descriptive hypothesis testing is done by using one sample test with a cut-off value of 3.41 with the results as listed in the One Sample Test table, it appears that all the indicators on the 4 variables have a significance number well below 0.05 . Thus it can be concluded that all variables in this study, namely transformational leadership, interaction competency, personality composition and employee performance can be said to have gone well.

\section{Direct Effect}

Structural model analysis that explains the effect test between variables is presented in the following path diagram: 


\section{International Journal of Business Management and Economic Review}

Vol. 3, No. 04; 2020

ISSN: 2581-4664

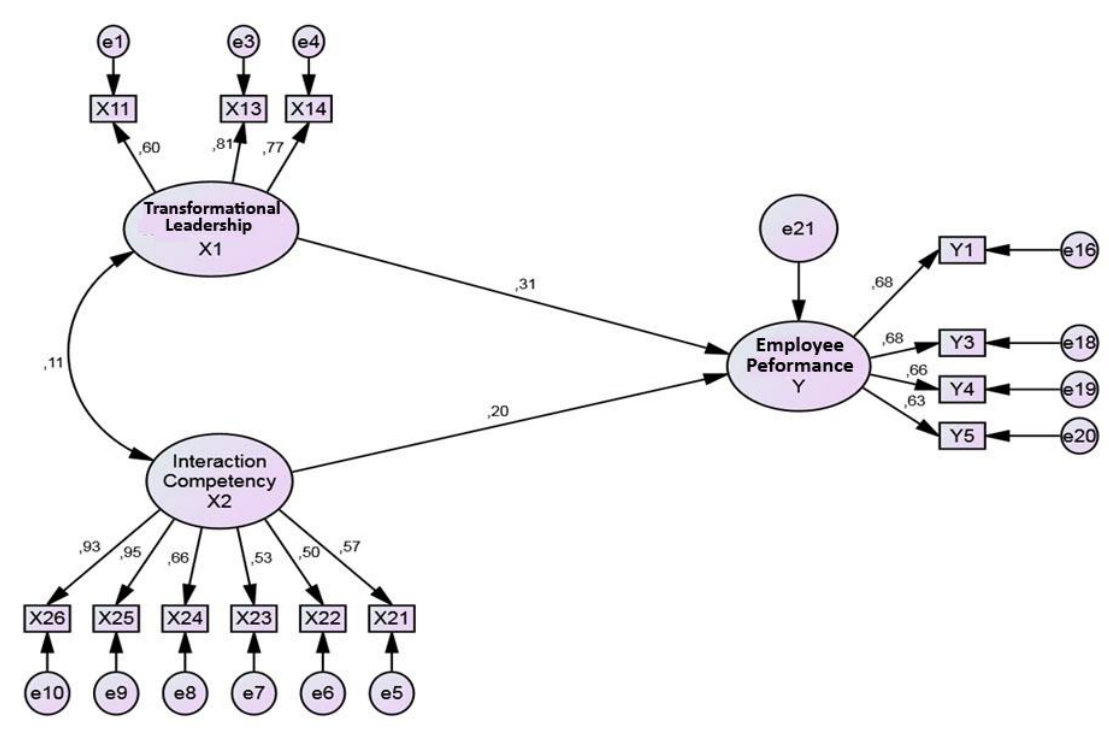

Figure 2. Regression Weight Structural Equational Model

The results of testing the hypothesis which are also tested through the full model after passing through the SEM assumptions, are more clearly found in the following table:

Table 2. Hypothesis Testing Result

\begin{tabular}{|l|l|l|l|l|l|l|}
\hline $\begin{array}{l}\text { Endogenous } \\
\text { Variables }\end{array}$ & & Exogenous Variables & $\begin{array}{l}\text { Estimate } \\
\text { Standar } \\
\text { d }\end{array}$ & $\begin{array}{l}\text { S.E } \\
\text { ・ }\end{array}$ & $\begin{array}{l}\text { C.R } \\
\cdot\end{array}$ & P \\
\hline $\begin{array}{l}\text { Employee_Peformance_ } \\
\text { Y }\end{array}$ & $\begin{array}{l}<-- \\
\text { Transformational_Leadership_ }\end{array}$ & 0.310 & 0.121 & 3.035 & $\begin{array}{l}0.00 \\
2\end{array}$ \\
\hline $\begin{array}{l}\text { Employee_Peformance_ } \\
\text { Y }\end{array}$ & $\begin{array}{l}<-- \\
\text { Interaction_Competency_X2 }\end{array}$ & 0.202 & 0.129 & 2.261 & $\begin{array}{l}0.02 \\
4\end{array}$ \\
\hline
\end{tabular}

Source: Primary Data, 2020 (processed)

From the results of the direct influence test in the above table it can be explained that:

1. H2 : The Effect of Transformational Leadership on Employee Performance

Based on Table 2, the estimated values obtained for testing the effect of X1 to Y show a CR value of 3.035 and a probability value of 0.002 . The resulting figures are sufficient for a requirement to accept $\mathrm{H} 2$, ie with a $\mathrm{CR}$ result higher than 1.96 and a probability result lower than 0.05. From this description it can be concluded that transformational leadership influences employee performance. In other words, if an organization wants to improve the performance of its employees, what needs to be done is to increase good transformational leadership. The magnitude of the coefficient of influence of transformational leadership on employee performance is 0.310 which means that every time there is an increase in one unit of transformational leadership that is done will have an impact on improving employee performance by $31.0 \%$. This conclusion is supported by research that has been reviewed 


\section{International Journal of Business Management and Economic Review}

Vol. 3, No. 04; 2020

ISSN: 2581-4664

by(Martin, Cormican, Sampaio, \& Wu, 2018);(Simic, Ristic, Milosevic, \& Ristic, 2017);(Benoliel \& Somech, 2014);(Kalsoom, Ali Khan, \& Sohaib Zubair, 2018);(Bachrach \& Mullins, 2019);(Paracha, Qamar, Mirza, \& Waqas, 2012);(Sundi, 2013)which stated that both transformational and transactional leadership have an impact on team performance. Employees who have a good level of performance because they have a good level of communication and good transformational leadership(Payne, 2005).

2. H3 : The Effect of Interaction Competency on Employee Performance

Based on Table 2, the estimated values obtained for testing the effect of Interaction Competency on employee performance show a CR value of 2.261 and also a probability value of 0.024 . The resulting figures are sufficient for a requirement to accept $\mathrm{H} 3$, ie with a CR yield higher than 1.96 and a probability result lower than 0.05 . From this description it can be concluded that Interaction Competency affects employee performance. In other words, if an organization wants to improve the performance of its employees, what needs to be done include increasing good Interaction Competency. The magnitude of the coefficient of influence of Interaction Competency on employee performance is 0.202 , which means that every time there is an increase in one unit of employee Interaction Competency conducted will have an impact on improving employee performance by $20.2 \%$. This conclusion is supported by research that has been reviewed by(Arafat, 2013)found that the salesperson's ability affected sales performance. Next(Wang, 2020)stated that subordinate and supervisor communication as well as weak peers will result in poor employee performance, and vice versa.(Pamuji, Kumadji, \& Hidayat, 2016)states that subordinate and supervisor communication as well as weak peers will result in poor employee performance, and vice versa.

\section{Moderation Effect}

1. H4: Personality Composition Moderates the influence of Leadership Style on Employee Performance

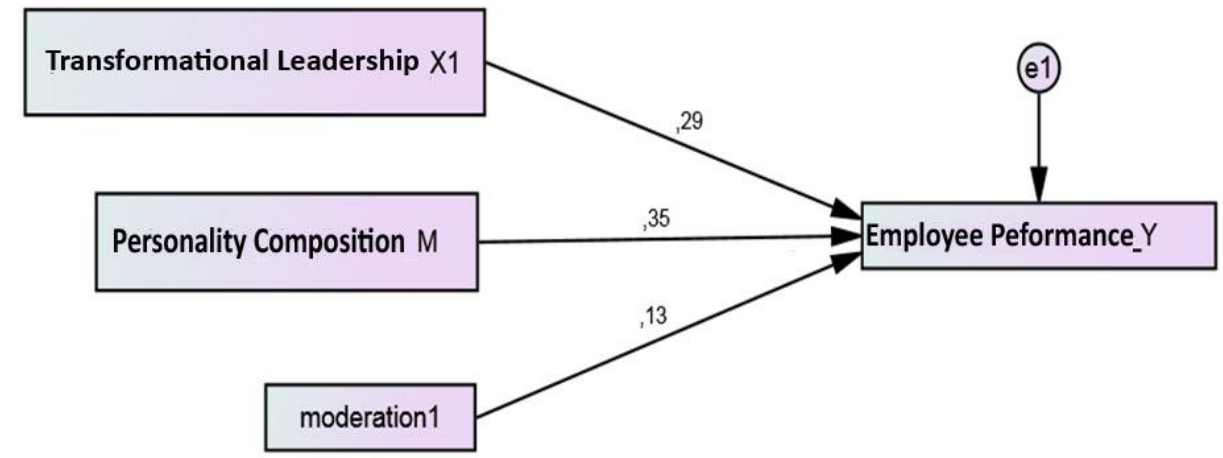

Figure 3. Regression Weight Structural Equational Model Moderation 1

To see whether there is a moderating effect on personality composition on the relationship of transformational leadership to employee performance, it can be seen in the table below. 


\section{International Journal of Business Management and Economic Review}

Vol. 3, No. 04; 2020

ISSN: 2581-4664

Table3. Regression Weight Structural Equational Model Moderation

\begin{tabular}{|l|r|l|l|c|c|l|}
\hline Endogenous variables & & Exogenous Varaiebel & $\begin{array}{l}\text { Standard } \\
\text { Estimate }\end{array}$ & S.E. & C.R. & P \\
\hline Employee_Peformance_Y & $<---$ & Transformational_Leadership_X1 & 0.289 & 0.064 & 4.387 & 0.000 \\
\hline Employee_Peformance_Y & $<---$ & Personality_Composition_M & 0.351 & 0.064 & 5.331 & 0.000 \\
\hline Employee_Peformance_Y & $<---$ & moderation1 & 0.132 & 0.060 & 2.012 & 0.044 \\
\hline
\end{tabular}

Source: AMOS Output Results, 2020 (processed)

Based on the test results of the moderation effects above, it is known that the influence of transformational leadership significantly on employee performance. This can be seen from the magnitude of the CR value of 4.387> 1.96 and the significance of 0.000 or $<0.05$. Furthermore, the influence of moderating personality composition variables significantly on employee performance with a CR value of 5.331 $>1.96$ and a probability value of $0.000<0.05$. While the moderating effect 1 is the result of multiplication of zscore exogenous variables with moderator $(\mathrm{X} 1 * \mathrm{M})$ known to be significant, this can be seen from the magnitude of the CR value of 2.012 or $<1.96$ and the significant value of 0.044 or $<0.05$. Thus it can be considered Pure Moderation. This means that the variable that the composition of personality moderates the influence of transformational leadership on employee performance. The result is supported by research conducted by(Martin et al., 2018)and(Benoliel \& Somech, 2014)found that shared leadership typologies, personality composition, and job complexity are moderating factors that positively influence the relationship between joint leadership and team performance.

2. H5: Personality Composition Moderates the effect of Interaction Competency on Employee Performance.

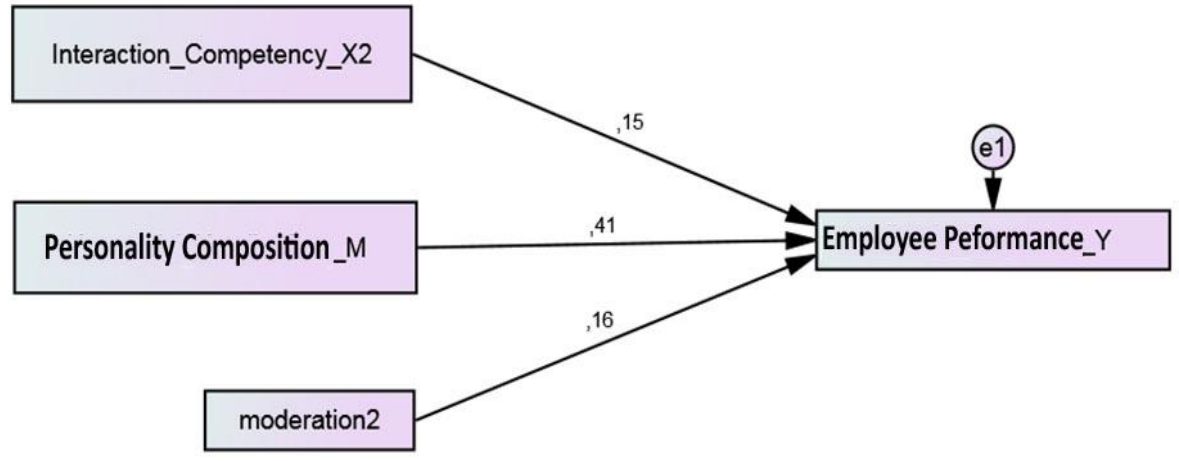

Figure 4. Regression Weight Structural Equational Model Moderation 2

To see whether there is a moderating effect on personality composition on the interaction competency relationship on employee performance, it can be seen in the following table: 
International Journal of Business Management and Economic Review

Vol. 3, No. 04; 2020

ISSN: 2581-4664

Table 4 .Regression Weight Structural Equational Model Moderation

\begin{tabular}{|l|l|l|l|l|l|l|}
\hline Endogenous variables & & Exogenous Varaiebel & $\begin{array}{l}\text { Estimat } \\
\text { e } \\
\text { Standar }\end{array}$ & $\begin{array}{l}\text { S.E } \\
\cdot\end{array}$ & $\begin{array}{l}\text { C.R } \\
\cdot\end{array}$ & P \\
\hline $\begin{array}{l}\text { Employee_Peformance_ } \\
\text { Y }\end{array}$ & $\begin{array}{l}<- \\
-\end{array}$ & $\begin{array}{l}\text { Transformational_Leadership_X } \\
1\end{array}$ & 0.155 & $\begin{array}{l}0.06 \\
5\end{array}$ & 2.338 & $\begin{array}{l}0.01 \\
9\end{array}$ \\
\hline $\begin{array}{l}\text { Employee_Peformance_ } \\
\text { Y }\end{array}$ & $\begin{array}{l}<- \\
-\end{array}$ & Personality_Composition_M & 0.408 & $\begin{array}{l}0.06 \\
5\end{array}$ & 6.173 & $\begin{array}{l}0.00 \\
0\end{array}$ \\
\hline $\begin{array}{l}\text { Employee_Peformance } \\
\text { Y }\end{array}$ & $\begin{array}{l}<- \\
-\end{array}$ & Moderation2 & 0.163 & $\begin{array}{l}0.07 \\
2\end{array}$ & 2.465 & $\begin{array}{l}0.01 \\
4\end{array}$ \\
\hline
\end{tabular}

Source: AMOS Output Results, 2020 (processed)

Based on the results of the moderation effect test above, it is known that the effect of interaction competency has a significant effect on employee performance. This can be seen from the magnitude of the CR value of 2.238> 1.96 and the significance of 0.019 or $<0.05$. Furthermore, the influence of personality composition moderating variable significantly influences employee performance with a CR value of $6.173>1.96$ and a probability value of $0.000<0.05$. While the moderation effect 2 is the result of multiplication of zscore exogenous variables with a moderator $(\mathrm{X} 2 * \mathrm{M})$ known to have a significant effect, this can be seen from the magnitude of the CR value of 2.465 or $>1.96$ and a significant value of 0.014 or $<0.05$. Thus it can be considered Pure Moderation. This means that personality composition variables moderate the effect of interaction competency on employee performance. This result is supportedby the research carried out by(Briggs, Funge-Smith, Subasinghe, \& Phillips, 2004) that saidemployees who have a good level of performance are because they have a good level of communication and good transformational leadership(Payne, 2005)and rejects the research conducted by(Phaneuf, Boudrias, Rousseau, \& Brunelle, 2016);(Strang, 2004);(Kalshoven, Den Hartog, \& de Hoogh, 2011)that stated transformational leadership is not affected by the composition of personality but when moderated by the organizational context, the composition of personality has an influence on leadership.

\section{CONCLUSION}

The resultshows that transformational leadership and interaction competency are significant on employee performance. Furthermore, personality composition can strengthen the influence of transformational leadership on employee performance. Personality composition can strengthen the effect of interaction competency on employee performance. This study provides managerial implications that to improve the performance of its employees, especially sales at PT. DuniaBarusa Aceh, what needs to be done is to increase transformational leadership, interaction competency and employee personality composition.

To improve the performance of its employees, especially employees in the sales department at PT. DuniaBarusa Aceh, what must be done, among others, is the improvement of good transformational leadership. Good transformational leadership can be improved by making employees feel comfortable when employees discuss each work problem, inspiring employees 


\section{International Journal of Business Management and Economic Review}

Vol. 3, No. 04; 2020

ISSN: 2581-4664

about ways to see problems that are very difficult for employees, telling employees how employees do their jobs properly and correctly in a way that is it is quite easy to understand and prevents employees from making their own decisions when there are problems.

Furthermore, to improve the performance of their employees, PT. DuniaBarusa Aceh must also improve its interaction competency. interaction competency can be improved by managing social relationships with others, being able to respond to consumer actions, being able to interact with people in any condition and situation, communicating with several people at once, being able to interact with others wherever they are and trying to be able to communicate long with people other.

Furthermore, to improve employee performance, the composition of personality must also be improved. Personality composition can be increased openly in providing work experience to others, working sincerely with a conscience, passionate about working and very enthusiastic, dominant, friendly, and communicative, happy to help others work colleagues and obey the rules of work and self-confidence in work.

For future studies, it is better to complete this research by including mediation variables in the models it builds. The application of mediation models especially for job satisfaction, organizational commitment, motivation and organizational behavior will give a fuller picture not only to complete references in developing employee performance, but also can provide deeper insights as input for leaders of PT. DuniaBarusa in understanding Human Resources that makes PT. DuniaBarusa as one of the leading car sales companies in Aceh in particular and Indonesia in general.

\section{REFERENCES}

Allport, G. W. (1943). Personality: a psychological interpretation. British Journal of Educational Psychology, 13(1), 48-50. $\quad$ https://doi.org/https://doi.org/10.1111/j.20448279.1943.tb02719.x

Arafat, R. (2013). Pengaruh Dimensi Sales Skill terhadap Kinerja Penjualan. Management Analysis Journal, 2(1), 110-118.

Bachrach, D. G., \& Mullins, R. (2019). A dual-process contingency model of leadership, transactive memory systems and team performance. Journal of Business Research, 96(November 2018), 297-308. https://doi.org/10.1016/j.jbusres.2018.11.029

Baron, R. M., \& Kenny, D. A. (1986). The moderator-mediator variable distinction in social psychological research: Conceptual, strategic, and statistical considerations. Journal of Personality and Social Psychology, 51(6), 1173.

Basri, H., \& Syafrizal, S. (2017). Peranmedia Sosial Twitter Dalam Interaksi Sosial Pelajar Sekolah Menengah Pertama di Kota Pekanbaru (studi kasus pelajar SMPN 1 kota Pekanbaru). Jurnal Online Mahasiswa Fakultas Ilmu Sosial Dan Ilmu Politik Universitas Riau, 4(2), 1-15.

Benoliel, P., \& Somech, A. (2014). The health and performance effects of participative leadership: Exploring the moderating role of the Big Five personality dimensions. European Journal of Work and Organizational Psychology, 23(2), 277-294. https://doi.org/10.1080/1359432X.2012.717689

Bernardin, H. J., \& Russell, J. E. A. (2012). Human Resource Management (6th ed.). New York: 
Vol. 3, No. 04; 2020

ISSN: 2581-4664

\section{McGraw-Hill.}

Briggs, M. R. P., Funge-Smith, S., Subasinghe, R., \& Phillips, M. (2004). Introductions and movement of Penaeus vannamei and Penaeus stylirostris in Asia and the Pacific. Bangkok: RAP Publication.

Colquitt, J. A., LePine, J. A., \& Wesson, M. J. (2011). Organizational. Behavior. New York: McGraw Hill.

Derlega, V. J., Winstead, B. A., \& Jones, W. H. (2004). Personality: Contemporary Theory and Research (3rd ed.). Boston: Cengage Learning.

Frank Ostroff. (1999). The Horizontal Organization: What the Organization of the Future Actually Looks Like and How it Delivers Value to Customers. New York: Oxford University Press.

Ghozali, I. (2017). Model Persamaan Struktural, Konsep dan Aplikasi dengan Program AMOS 24 Update Bayesian SEM (Edisi 7). Semarang: Badan Penerbit Universitas Diponegoro.

Greenhaus, J. H., \& Callanan, G. A. (2006). Encyclopedia of Career Development. Thousand Oaks: SAGE Publications, Inc.

Hair, J. F., Hult, G. T. M., Ringle, C., \& Sarstedt, M. (2016). A Primer on Partial Least Squares Structural Equation Modeling (PLS-SEM) (2nd ed.). Thousand Oaks: Sage Publications, Inc.

Hall, C. S., \& Lindzey, G. (1993). Psikologi Kepribadian 1 Teori-Teori Psikodinamik (Klinis). Yogyakarta: Kanisius.

Kalshoven, K., Den Hartog, D. N., \& de Hoogh, A. H. B. (2011). Ethical Leader Behavior and Big Five Factors of Personality. Journal of Business Ethics, 100(2), 349-366. https://doi.org/10.1007/s10551-010-0685-9

Kalsoom, Z., Ali Khan, M., \& Sohaib Zubair, S. (2018). Impact of Transactional Leadership and Transformational Leadership on Employee Performance: A Case of FMCG Industry of Pakistan. Industrail Engineering Letters, 8(3), 23-30.

Kreitner, R., \& Kinicki, A. J. (2013). Perilaku Organisasi Bk.2 (9th ed.). Jakarta: Salemba Empat.

Martin, J., Cormican, K., Sampaio, S. C. B., \& Wu, Q. (2018). Shared leadership and team performance: An analysis of moderating factors. Procedia Computer Science, 138, 671679. https://doi.org/https://doi.org/10.1016/j.procs.2018.10.089

Mead, G. H., \& Morris, C. W. (1967). Mind, Self, and Society from the Standpoint of a Social Behaviorist. Chicago: The University of Chicago Press.

Pamuji, D., Kumadji, S., \& Hidayat, K. (2016). Pengaruh Kompetensi Komunikasi Terhadap Direct Selling Serta Dampaknya Pada Volume Penjualan (Survei pada Seller Tupperware PT. Vinivici Prima Lestari di Surabaya). Jurnal Administrasi Bisnis S1 Universitas Brawijaya, 31(1), 132-139.

Paracha, B. M. U., Qamar, A., Mirza, A., \& Waqas, H. (2012). " Impact of Leadership Style ( Transformational \& Transactional Leadership ) On Employee Performance \& Mediating Role of Job S ... " Impact of Leadership Style ( Transformational \& Transactional Leadership ) On Employee Performance \& Mediating Role of Jo. Global Journal of Management and Business Research, 12(4), 54-64.

Payne, H. J. (2005). Reconceptualizing Social Skills in Organizations: Exploring the Relationship between Communication Competence, Job Performance, and Supervisory 


\section{International Journal of Business Management and Economic Review}

Vol. 3, No. 04; 2020

ISSN: 2581-4664

Roles. Journal of Leadership \& Organizational Studies, 11(2), 63-77. https://doi.org/10.1177/107179190501100207

Phaneuf, J. É., Boudrias, J. S., Rousseau, V., \& Brunelle, É. (2016). Personality and transformational leadership: The moderating effect of organizational context. Personality and Individual Differences, 30-35. https://doi.org/10.1016/j.paid.2016.06.052

Qadariah, Majid, M. S. A., \& Idris, S. (2019). Mediating Effect of Employee Performance on the Influences of Job Embeddedness, Self-efficacy, and Organizational Commitment on the Public Organizational Performance. IOSR Journal of Business and Management (IOSR$J B M), 21(2), 55-62$. https://doi.org/10.9790/487X-2102015562

Robbins, S. P., \& Judge, T. A. (2014). Buku Perilaku Organisasi Buku 2 (Edisi ke-1; alih bahasa D. Angelica, Ed.). Salemba Empat.

Silva, R. V. Da, \& Alwi, S. F. S. (2008). Online brand attributes and online corporate brand images. European Journal of Marketing, 42(9), 1039-1058. https://doi.org/https://doi.org/10.1108/03090560810891136

Simic, J., Ristic, M. R., Milosevic, T. K., \& Ristic, D. (2017). The Relationship Between Personality Traits and Managers` Leadership Styles. European Journal of Social Sciences Education and Research, 11(2), 194. https://doi.org/10.26417/ejser.v11i2.p194-199

Strang, S. E. (2004). Big Five Personality and Leadership Development Levels as Predictors of Leader Performance. 53(9), 4-5.

Sundi, B. K. (2013). Effect of Transformational Leadership and Transactional Leadership on Employee Performance of Konawe Education Department at Southeast Sulawesi Province *). International Journal of Business and Management Invention ISSN (Online, 2(12), 2319-8028.

Timpe, A. D. (2012). Seri Manajemen Sumber Daya Manusia (A. D. Ti, Ed.). Jakarta: PT Elex Media Komputindo.

Wang, P. (2020). Superior firm performance under conditional communication between top hierarchy and the subordinates. Economic Modelling, 90, 516-526. https://doi.org/https://doi.org/10.1016/j.econmod.2020.01.024

Whittaker, S., Frohlich, D. M., \& Daly-Jones, O. (1994). Informal workplace communication: What is it like and how might we support it? Conference on Human Factors in Computing Systems. https://doi.org/10.1145/191666.191726

Wibowo. (2015). Perilaku Dalam Organisasi (2nd ed.). Medan: Raja Grafindo Persada. 